\section{Analysis of pedological factors and USCS in the contact area of Đakovo loess plateau and Dilj gora, Croatia}

The Mining-Geology-Petroleum Engineering Bulletin UDC: $623.3: 623.6$

DOI: 10.17794/rgn.2020.1.2

Original scientific paper

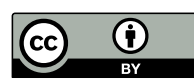

\author{
Hrvoje Heštera ${ }^{1}$ \\ ${ }^{1}$ Croatian Defence Academy “Dr Franjo Tuđman”, Ilica 256b, 10000 Zagreb, Croatia, ORCID: https://orcid.org/0000-0003-4609-8368
}

\begin{abstract}
The pedological factors concerning the Unified Soil Classification System (USCS) in the contact area of Đakovo loess plateau and Dilj gora have been explored. The study was carried out to create a cross-country mobility map for vehicles. The spatial GIS analysis included soil units of Basic Soil Map (BSM) at a scale of 1:50ooo, which, according to the World Reference Base (WRB), contain within themselves the distribution of soil units, particle size distribution according to the United States Department of Agriculture (USDA) soil classification and organic content, as well as data from the Basic Geological Map (BGM) at a scale of 1:10oooo, together with the information on the original parent material from which the soils originate. Field sampling (72 samples) and laboratory sample analysis were performed according to the USCS. The samples were collected at the same locations (50 samples) as the profiles which had been extracted during the development of BSM to enable a comparison of the two classification systems. The analysis did not confirm a clear statistical connection between the USDA and USCS. The compatibility of BSM pedological units and low plasticity clays (CL) is clearly visible in all units, except for the units located on the alluvium. The presence of low plasticity clay (CL) and high plasticity clay $(\mathrm{CH})$ has been confirmed in the stagnosols on the alluvium. By incorporating the geological basis into the spatial analysis, low plasticity clays were found to belong to the Quaternary source material, whereas high plasticity clays were formed on the parent substrate of Neogene age. Data analysis and cartographic representation of the results according to the Waterways Experiment Station (WES) Method of the cone index were obtained using fuzzy logic. The principles of fuzzy logic were used at the boundaries of pedological units due to the inability to define clear boundaries or the cessation of a particular type of soil's presence.
\end{abstract}

Keywords:

USDA soil classification, USCS, soil mechanics, fuzzy logic, cross-country mobility

\section{Introduction}

Spatial information on soil properties is vital for many areas of human interest, including agronomy, geology, biology, engineering, forestry, and the military. This paper focuses on the research of soil factors on vehicle mobility, as well as on the representation and mapping of the physical and index properties of the soil. From the aspect of vehicle mobility, soil represents the most dynamic spatial component, the reason being the fact that changes in weather conditions (primarily precipitation) change the physical and all other soil properties. Most research and methods applied to determine the mobility of the vehicle relating to the soil are carried out by the military (Heštera and Pahernik, 2018). Due to its userfriendliness, the most widespread is the WES cone index method (Meyer, 1976; Wong, 2001), followed by the Mean maximum pressure method (Rowland, 1972) and the Bevameter method (Bekker, 1956). In applying these methods, USCS engineering classification is used

Corresponding author: Hrvoje Heštera

hrvoje.hestera@morh.hr because it contains the descriptions of physical and index properties of all types of soils. For the purpose of mapping vehicle mobility by the WES method, the rating cone index (RCI) of soil bearing capacity is used for each of the 16 soil groups of the USCS. RCI is an index of soil shear-strength that includes consideration of the soil response of strength losses under vehicle movement and it is a product of the cone index and the remold index. The movement speed of a vehicle depends on the soil RCI value and vehicle cone index (VCI) which is calculated from the mobility index (Priddy and Willoughby, 2006; Stevens et al., 2013). Indices of soil bearing capacity are determined by empirical and laboratory research done by NATO member countries. The key factor in cross-country vehicle mobility is soil strength, which affects the performance of vehicles in off-road conditions. It is important in the construction of roads, as well as in agriculture, mining, forestry and military operations. The application of the USCS in the WES method is very good because it describes how changes in the soil moisture content are reflected in the soil bearing capacity. 


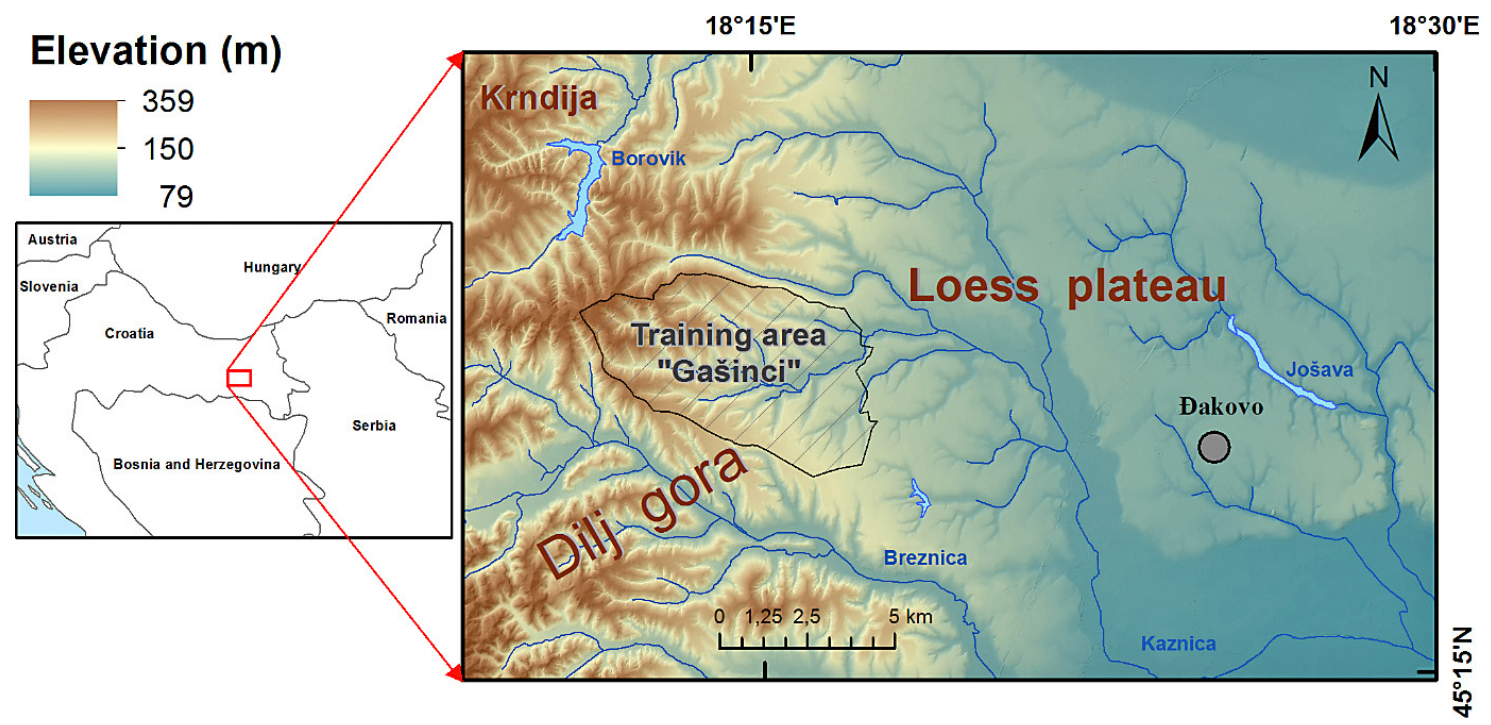

Figure 1: Research area - physical map

A basic parameter for vehicle mobility research on ground is the size of the soil particles. The USDA classification is the most commonly used granulometric soil classification in agronomy based on particle size distribution within the soil texture triangle. The USCS also uses particle size distributions during classification, as well as the Atterberg limits and indices to define silts and clays. The Atterberg limits excellently describe the behaviour of the soil during the change of soil moisture, which is extremely important because the changes in the soil moisture are directly reflected on vehicle mobility.

The basic problem of soil trafficability research arises from the fact that there is a lot of data on the particle size distribution of the soil particles, according to various classifications and particle size limits, but no data sources are available for the USCS. Several studies and models have been established to describe the correlation between the USDA and the USCS, which are summarized in the paper written by García-Gaines and Frankenstein (2015). In their review paper, García-Gaines and Frankenstein (2015) conclude that the correlations of the two classification systems need to be observed with caution, claiming that laboratory tests should be carried out to achieve the complete mapping accuracy according to the USCS. Consequently, many studies have focused on the correlation and modelling to predict and define soil groups according to the USCS (Frankenstein, 2008; Gambill et al., 2016). When correlating and modelling the prediction of the USCS soil group by grain size distribution, all available data related to soil properties is used, such as organic matter, drainage class, moist bulk density, available water capacity, etc. (Gambill et al., 2016).

On the other hand, those who hold most of the available data and research on the formation processes and processes related to the soil are pedologists, geologists and geomorphologists. All available sources on spatial information are used for soil property research purposes.
Remote sensing methods are popular because they are less expensive and are an integral part of the approach known as "Digital soil mapping", in which multiple linear regression, neural networks, random forest, fuzzy logic, cokriging, regression kriging etc., are used (Hengl and Reuter, 2009; Lagacherie, 2007; Malvić, 2008; McBratney et al., 2003; Mesić-Kiš, 2017; Zhu et al., 2001). Then there are aerial photo interpretation methods (Soil Science Division Staff, 2017), a terrain-based method (McKenzie and Ryan, 1999) and a geopedological approach to soil mapping (Zinck et al., 2016). The only accurate and substantiated data is derived from field research and laboratory analysis. For the territory of the Republic of Croatia, BSM is currently the only relevant cartographic source of pedological features, although mapping of the entire area has not been fully completed (only hand-interpolated maps and a few unfinished sheets are available) (Bogunović and Rapaić, 1993). The development of the BSM was based on aerial photo interpretation methods, field research and laboratory analysis, to improve agricultural production. Map units of this map are defined on the basis of several major criteria such as soil moisture, the evolutionary stage of the soil, the type of profile structure, the sequence of horizons, as well as on the processes of transformation and migration of mineral and organic matter and similarities in the physicochemical characteristics of the horizons. Consequently, they were subdivided into possible subtypes, varieties and forms (Husnjak, 2014). Considering its systematic nature and high value of data, the BSM is a crucial primary source of data for all pedosphere research in the Republic of Croatia.

\section{Methods}

The research area, structuring of data sources, sampling sites, sampling and analytical techniques are discussed below. 


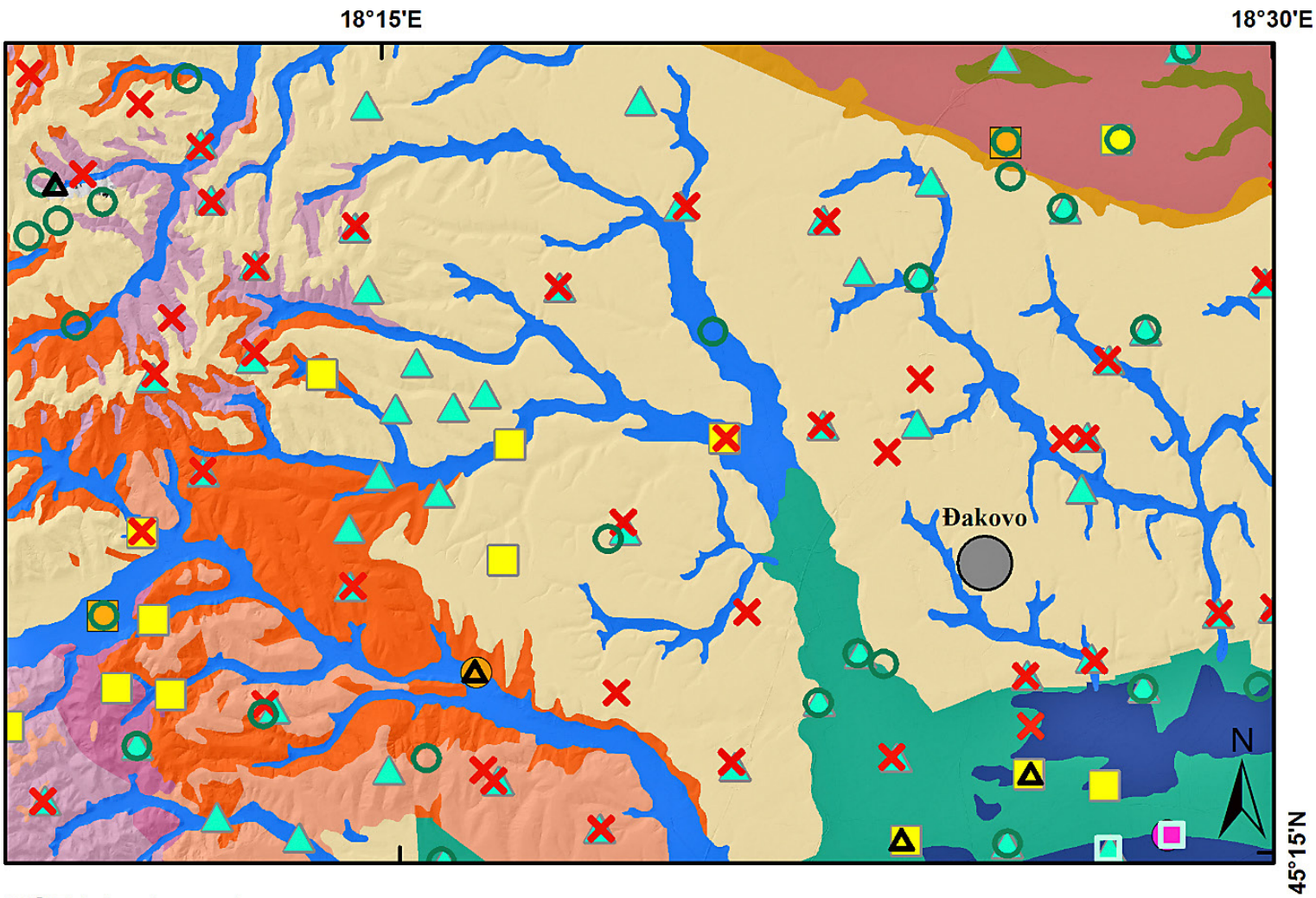

USDA texture classes

Clay $\Delta$ Silty Clay $\mathbf{O}$ Silty Clay Loam $\mathbf{X}$ Silty Loam

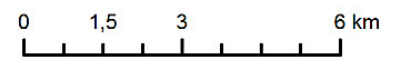

\section{USCS group name}
$\square \mathrm{CH}$ (High Plasticity Clay)
$\mathrm{CL} / \mathrm{CH}$ (Low/High Plasticity Clay)
$\mathrm{MH} / \mathrm{CH}$ (High Plasticity Silt/Clay)
CL (Low Plasticity Clay)
$\mathrm{MH}$ (High Plasticity Silt)

\section{Geological units}
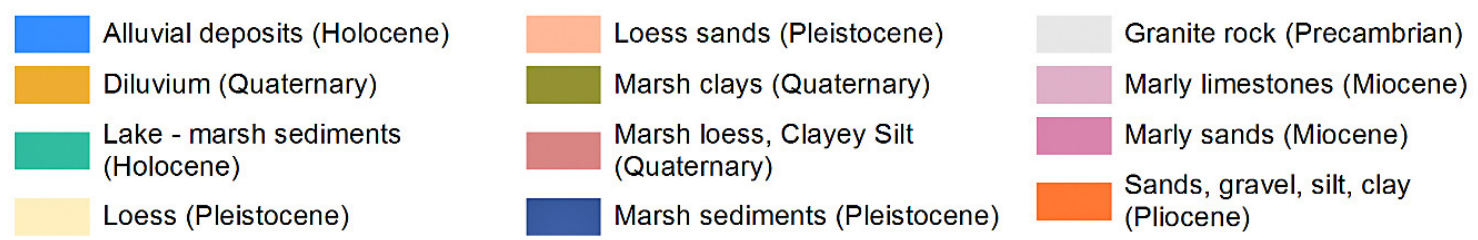

Figure 2: Redrawn Basic geological map in 1:10oooo scale, made according sections of sheets L 34-97 Slavonski Brod (Šparica et al., 1986) and L 34-85 Našice (Korolija and Jamičić, 1989) with the locations of USDA and USCS samples

\subsection{Research area}

The research area is located between $\mathrm{N} 45^{\circ} 15^{\prime}$ and $\mathrm{N}$ $45^{\circ} 25^{\prime}$ latitude and E $18^{\circ} 08^{\prime}$ and E $18^{\circ} 30^{\prime}$ longitude, while in the broader geographical sense, it is a part of eastern Slavonia (see Figure 1). In geomorphological, geological and pedological terms, the area is heterogeneous (see Figure 2 and Figure 3). The central part of the study area is the Đakovo loess plateau with a triangular shape and a decreasing slope from west to east. The area is a hilly highland intersected by numerous valleys of the Kaznica and Jošava rivers, with tributaries that together form the watershed between the Drava - Danube and Sava basins. The plateau of hilly areas mainly consist of Pleistocene eolian sediment - loess, with loamy and clayey sediments. The hilly highland area in the west is strongly dissected with intensive trench erosion in the lower third of the slope, composed of PlioPleistocene sediments and younger Neogene-Pliocene sediments. Numerous smaller or larger streams and rivers spring in the deep valleys of the hilly highland area and flow into the lowland area (Bogunović, 1973a; Vidaček, 1973a).

\subsection{Data sources structuring}

During the research, the GIS application of the ERSIArcGIS firmware version 10.4.1 was used for digitiza- 


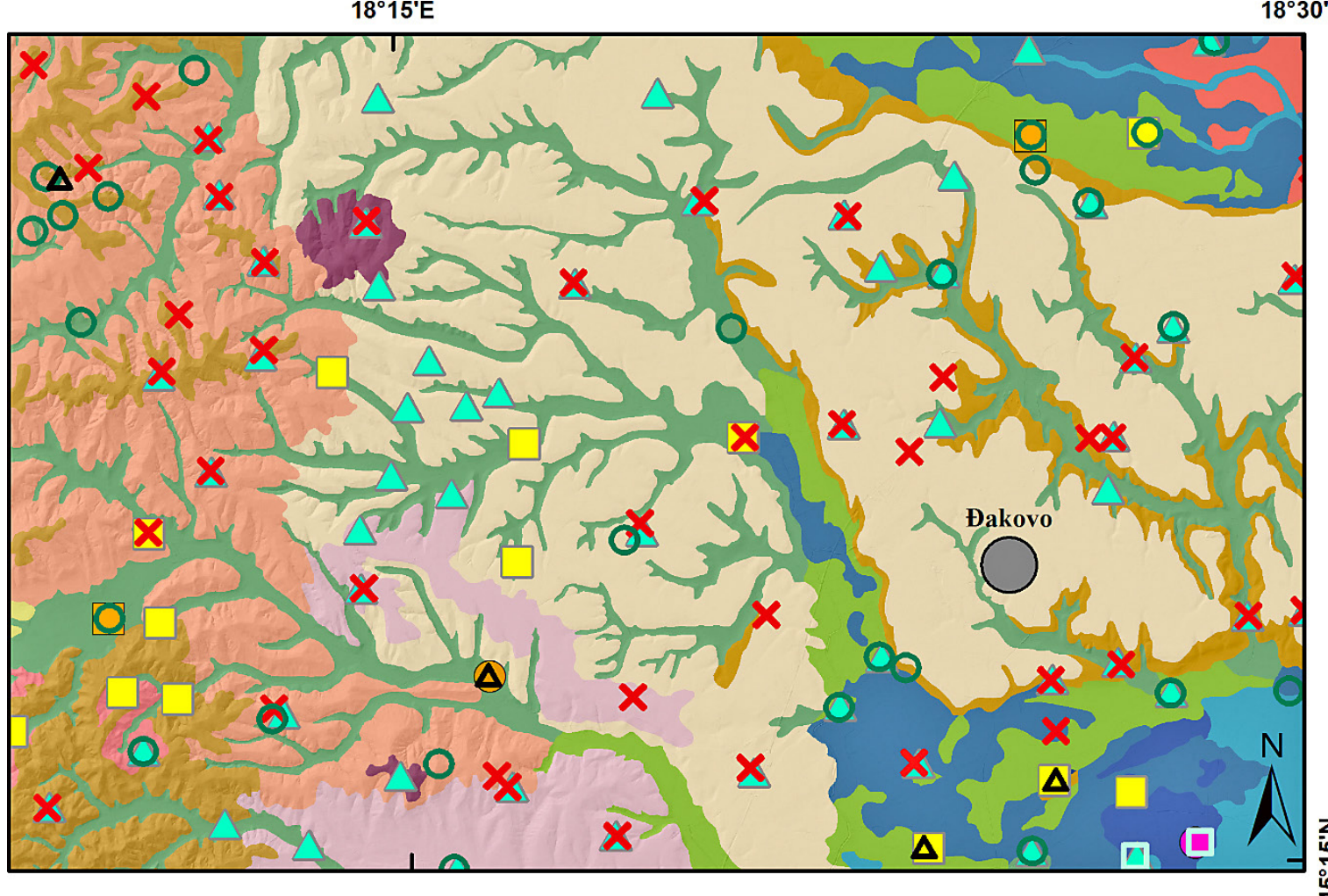

USDA texture classes
Clay
$\Delta$ Silty Clay
Silty Clay Loam
Silty Loam

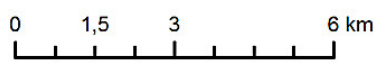

\section{USCS group name}

CH (High Plasticity Clay)

CL/CH (Low/High Plasticity Clay)

$\mathrm{MH} / \mathrm{CH}$ (High Plasticity Silt/Clay)

$\triangle \mathrm{CL}$ (Low Plasticity Clay)

$\mathrm{MH}$ (High Plasticity Silt)

\section{WRB soil group name}

Albeluvisol
Albeluvisol - Dystric Cambisol
Anthrosol
Dystric Cambisol
Fluvisol - Stagnosol

\begin{tabular}{|l|}
\hline Leptosol - Regosol \\
\hline Luvisol \\
\hline Luvisol - Eutric cambisol \\
\hline Luvisol - Regosol \\
Regosol \\
\hline
\end{tabular}

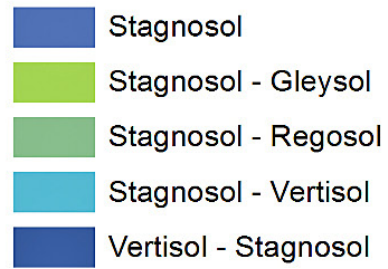

Figure 3: Redrawn Basic pedological map in 1:50ooo scale, made according sections of sheets Slavonski Brod 2 (Vidaček, 1973b) and Vinkovci 1 (Bogunović, 1973b) with locations of USDA and USCS samples

tion of analogue cartographic sources, vectorization, spatial analysis and cartographic interpretation. The sheets of BGM Slavonski Brod (L 34-97) and Našice (L 34-85) were digitized for field research purposes and spatial analysis of the obtained results (see Figure 2). The original analogue pedological data of BSM (scale 1:50000) of the Republic of Croatia were also digitized, that is, parts of Slavonski Brod 2 and Vinkovci 1 sheets (see Figure 3). The data on the collected pedological profiles and pedological units taken from the research studies of the above-mentioned sections of the BSM maps, which contain a detailed description of the cartographic units and descriptive data about the physical properties of the investigated soil profiles, were used in the analyses. The terms and systematization of pedological features were defined by Husnjak (2014) according to the WRB.

In developing the BSM, particle size distribution analysis of soil profiles was performed by a pipette method, with Na-pyrophosphate preparation and texture classification according to Soil Survey Staff (1951). Soil fractions are divided by sizes: $2-0.2 \mathrm{~mm}, 0.2-$ $0.05 \mathrm{~mm}, 0.05-0.02 \mathrm{~mm}, 0.02-0.002 \mathrm{~mm}$ and those less than $0.002 \mathrm{~mm}$ according to Soil Survey Staff $\mathbf{( 1 9 5 1 )}$. The textural classification of the original data within the profile was conducted at different depths, i.e. according 
to the corresponding basic pedogenetic horizons. Many textural classifications depend on the proportions of fractions (sand, silt and clay) and size limits of the fractions. In this research, particulate fractions were classified according to the USDA classification because of the comparability of numerous papers that have been published about the vehicle mobility and soil properties, where the USDA classification was used (GarcíaGaines and Frankenstein, 2015). Depths of up to 50 $\mathrm{cm}$ have been considered in the classification of soil according to the USDA classification because this is the reference depth to which the soil bearing capacity is measured by the WES method. Particle sizes within the present pedogenetic horizons up to $50 \mathrm{~cm}$ in depth were classified in proportion to the depth content. Among other results of the analyses that could be used in the research (organic matter, porosity, water capacity, air capacity, specific volume weight and specific soil weight) obtained during the making of the BSM, only the data on the organic matter was consistent throughout the study area. Other data on soil physical properties was not used for spatial analyses due to the incompleteness of the data.

\subsection{Sampling sites, sampling and analytical techniques}

The number of field samplings (72) for conducting soil analyses according to the USCS was determined based on the present source data of pedological profiles (77) explored in the process of the BSM development. The selection of soil sampling sites for laboratory analysis was defined in two steps:

- All present pedological units were allocated the number of samples corresponding to their spatial ratio in the entire research area (see Table 1).

- Sampling locations within the pedological units were predefined in relation to the profiles analysed according to the USDA classification (50 sites). Unless there was a USDA profile in the area of interest, locations (22 sites) were defined by random selection within the pedological unit. It should be noted that the polygons within the military training area Gašinci (see Figure 1) were favoured given the objectives and purposes of the future research of vehicles cross-country mobility.

Soil sampling in the field was conducted over a period between September $25^{\text {th }}$ and October $24^{\text {th }}, 2017$ with a field sampler. A total of 72 samples were collected in the study area covering $510 \mathrm{~km}^{2}$, with a sampling density of 1 sample per $7 \mathrm{~km}^{2}$. Samples were collected at a depth of $60 \mathrm{~cm}$ and transported to the laboratory in a protective film, where the upper $50 \mathrm{~cm}$ was included into analyses. There they were tested for physical and index properties, and the following properties were determined:

- Moisture in the natural state according to the standard ASTM D2216-10 (2010),
Table 1: Ratio of covered area by soil types and samples taken for the laboratory analysis for USCS.

\begin{tabular}{|l|c|c|c|c|}
\hline $\begin{array}{l}\text { World Reference } \\
\text { name (WRB) soil }\end{array}$ & $\begin{array}{c}\text { Area } \\
\left(\mathrm{km}^{2}\right)\end{array}$ & $\begin{array}{c}\text { Share } \\
\text { in total } \\
\text { area } \\
(\%)\end{array}$ & $\begin{array}{c}\text { Number } \\
\text { of } \\
\text { samples } \\
\text { for USCS }\end{array}$ & $\begin{array}{c}\text { Share in } \\
\text { overall } \\
\text { samples } \\
(\%)\end{array}$ \\
\hline Albeluvisol & 27.8 & 5.4 & 5 & 6.9 \\
\hline $\begin{array}{l}\text { Albeluvisol } \\
\text { - Dystric Cambisol }\end{array}$ & 68.6 & 13.4 & 4 & 5.6 \\
\hline Anthrosol & 3.9 & 0.8 & 2 & 2.8 \\
\hline Dystric Cambisol & 30.1 & 5.9 & 5 & 6.9 \\
\hline Fluvisol - Stagnosol & 33.0 & 6.5 & 5 & 6.9 \\
\hline Leptosol - Regosol & 2.4 & 0.5 & 1 & 1.4 \\
\hline Luvisol & 193.6 & 38.0 & 15 & 20.8 \\
\hline Luvisol - Regosol & 25.8 & 5.1 & 5 & 6.9 \\
\hline Regosol & 0.4 & 0.1 & 0 & 0.0 \\
\hline Stagnosol & 4.8 & 0.9 & 2 & 2.8 \\
\hline Stagnosol - Gleysol & 31.1 & 6.1 & 6 & 8.3 \\
\hline Stagnosol - Regosol & 80.5 & 15.8 & 20 & 27.8 \\
\hline Stagnosol - Vertisol & 7.8 & 1.5 & 1 & 1.4 \\
\hline Vertisol - Stagnosol & 0.1 & 0.0 & 1 & 1.4 \\
\hline$\Sigma$ & 509.9 & 100.0 & 72 & 100.0 \\
\hline & & & & \\
\hline
\end{tabular}

- The Atterberg limits (plasticity limit, liquid limit and plasticity index) according to the standard ASTM D4318-17e1 (2017),

- The particle size distribution of the soil according to the standard ASTM D422-63(2007)e2 (2007).

A Casagrande device was used for liquid limits determination. A standard set of sieves (sieve No. 4, 10, 20, 40,60 and 200) with sieve opening sizes: $4.75 \mathrm{~mm} 2.00$ $\mathrm{mm}, 0.85 \mathrm{~mm}, 0.425 \mathrm{~mm}, 0.25 \mathrm{~mm}$ and $0.075 \mathrm{~mm}$ was used for grain size analysis. The sieving method was applied. The hydrometer method was used to determine the particle size distribution of the fine-grained soil fraction. Based on the summary test results and data on the natural soil moisture, the liquidity index and the consistency index, i.e. the soil consistency state, were also determined. The summary results enabled the classification of soil according to ASTM D2487-17 (2017).

The visual programming language Model Builder, which is the part of the ArcGIS platform, was used to map the results of the analysis. For the cartographic interpretation of the results, the principle of fuzzy logic was used, in such a way that polygons of identical pedological soil groups were combined according to the RCI WES method (Hofmann et al., 2013). The inner buffer zone $(30 \mathrm{~m})$ was created on the polygons, which were then extended by $60 \mathrm{~m}$ with the help of the Euclidean distance tool. Before the final reunification of the polygons, the Fuzzy membership tool with a linear function option was used to assign final values for each soil group. 


\section{Results and discussion}

The basic premise before conducting field research and laboratory analyses was to test the opportunity of using BSM pedological data according to the USDA classification to make a mobility map of vehicles. According to the results of the laboratory and spatial analysis, Table 2 shows that there is no clear relationship between the two classification systems, except for the high correlation of results between Silty Loam (SL) and CL. The reason for the discrepancy may be the small number of samples (1 sample on $7 \mathrm{~km}^{2}$ ) or the high geologicalpedological heterogeneity of the area.
A more realistic representation of the analysis results can be seen when the results are set within the original classification system (see Figure 4 and Figure 5). Figure 4 shows, for example, that the $\mathrm{CL}$ and $\mathrm{CH}$ groups spread over three USDA textural classes. On the other hand, Figure 5 shows that all USCS results are located in two groups of soils that belong to fine-grained soils, that is, to inorganic clays, which is visible in the plasticity diagram. Only one sample is the exception - High Plasticity Silt (MH), which is taken from Vertisol-Stagnosol (see Figure 3). Having the above-mentioned exception in mind, we can say that the results are extremely uniform; they belong to two groups of inorganic clays.

Table 2: Matrix of spatially related samples (50) from USDA texture classification (source: BPM) and USCS soil group (laboratory results)

\begin{tabular}{|l|c|c|c|c|}
\hline & \multicolumn{4}{|c|}{ USDA texture group (number and distribution of samples in USCS) } \\
\hline USCS soil group & C (Clay) & SC (Silty Clay) & SCL (Silty Clay Loam) & SL (Silty Loam) \\
\hline CL (Low Plasticity Clay) & $1(50 \%)$ & - & $10(72 \%)$ & $29(91 \%)$ \\
\hline CH (High Plasticity Clay) & - & $1(50 \%)$ & $2(14 \%)$ & $3(9 \%)$ \\
\hline CL/CH (Low/High Plasticity Clay) & - & - & $2(14 \%)$ & - \\
\hline MH/CH (high plasticity silt/clay) & - & $1(50 \%)$ & - & - \\
\hline MH (High Plasticity Silt) & $1(50 \%)$ & - & - & - \\
\hline
\end{tabular}

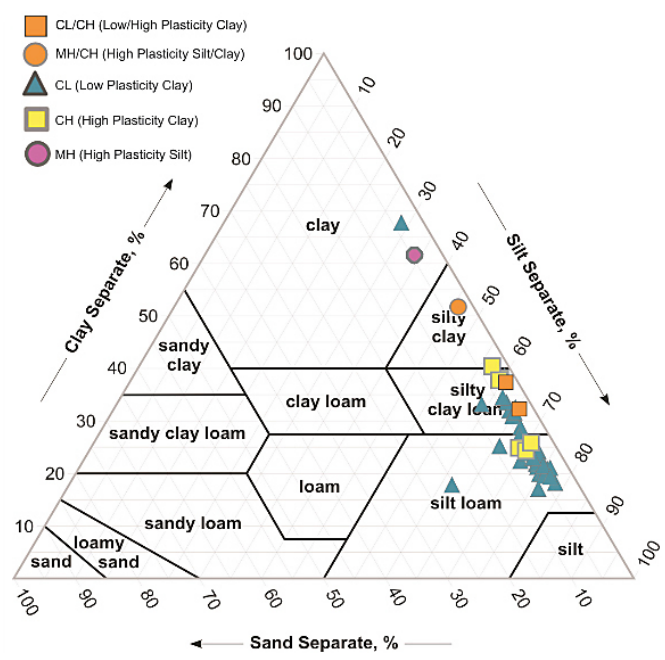

Figure 4: Distribution of spatial analysis results according to the USCS on the USDA textural triangle

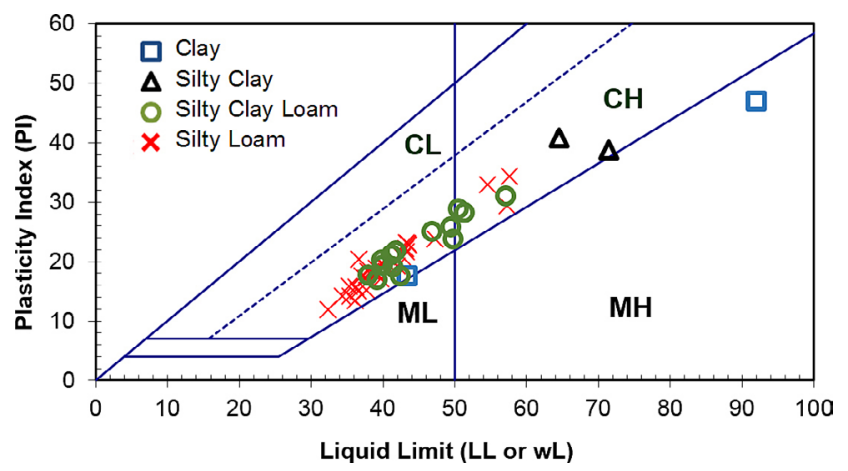

Figure 5: Distribution of spatial analysis results according to the USDA classification on the plasticity chart
Due to the observed discrepancies between the two classification systems, spatial analyses of the samples over BSM pedological units were conducted. In the results of the spatial analysis shown by the plasticity diagram in Figure 6, we can notice certain statistical regularities. The CL group is representative of all pedological units, and the results are well grouped with all pedological units except for those in which the Stagnosols are the predominant group.

Spatial analysis of samples taken from alluvial deposits (see Figure 2) and stagnosol soils (see Figure 3); Stagnosol, Stagnosol-Gleysol, Stagnosol-Vertisol and Vertisol-Stagnosol indicate the highest dispersion of results according to the USCS. These soil types are represented by $\mathrm{CL}$ and $\mathrm{CH}$, and it is not possible to clearly define the soil group according to the USCS based on the pedological map. Consequently, further analysis reveals that there is regularity and a grouping of the samples related to the chronostratigraphic characteristics of the parent material present in the substrate (see Figure 7). In the western part of the research area, there is a domination of the processes of fluvial sedimentation, while in the south-eastern and north-eastern parts the processes of sediment accumulation originally brought from the western part dominate. Soil particles along the watercourses in the western part of the study area (right tributary of the Kaznica River and Breznica stream) are a mixture of Miocene and Pliocene ages. The soils formed by the transport and deposition of the materials from these chronostratigraphic epochs belong to the $\mathrm{CH}$ soil group or are close to the liquid limit line (2 samples) which separates the soil groups. The reason for this is the 

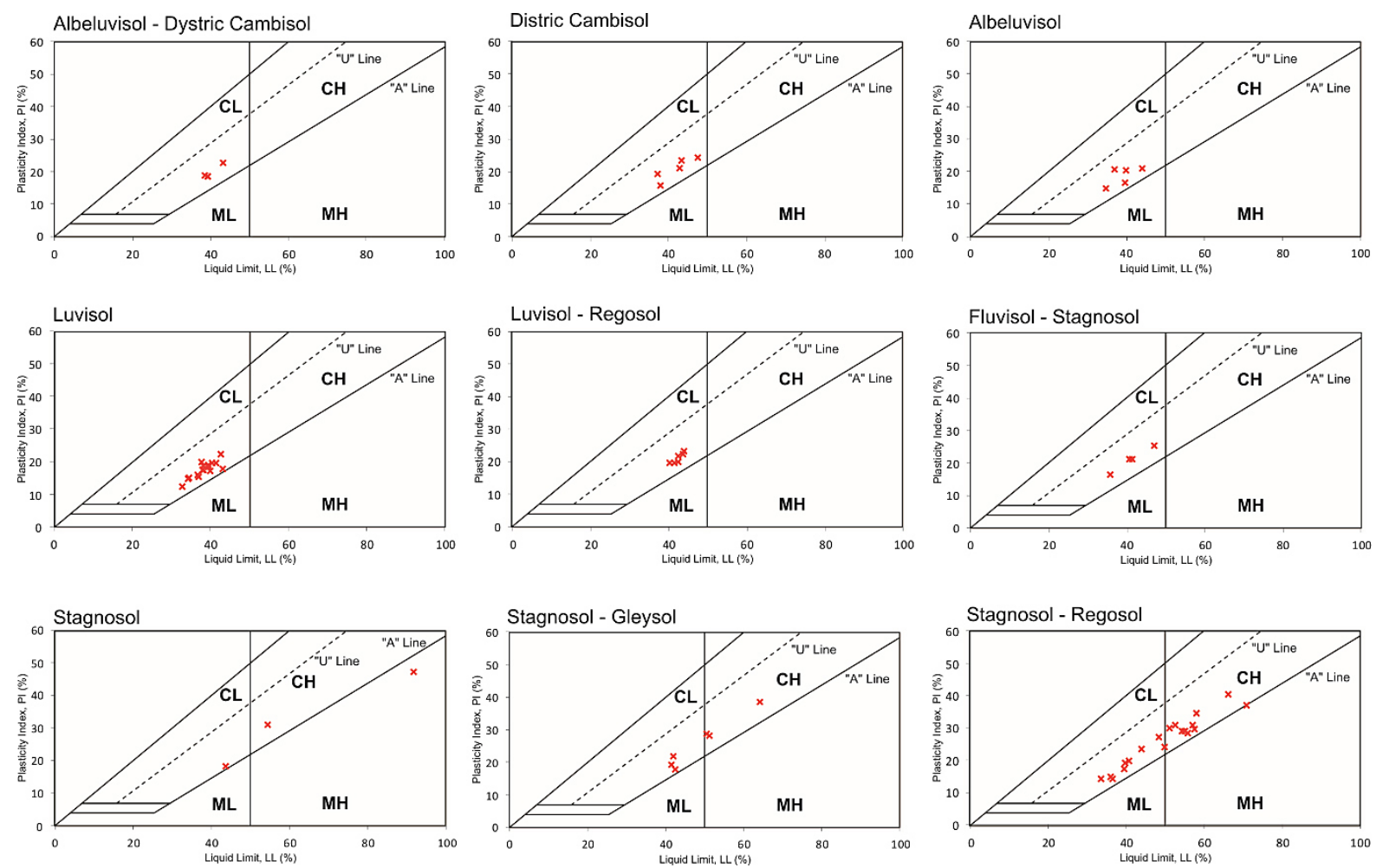

Figure 6: USCS samples distribution* on the plasticity chart among WRB soil groups

* Soil units with 1 or 2 taken samples are excluded from the results presentation (see Table 1 )
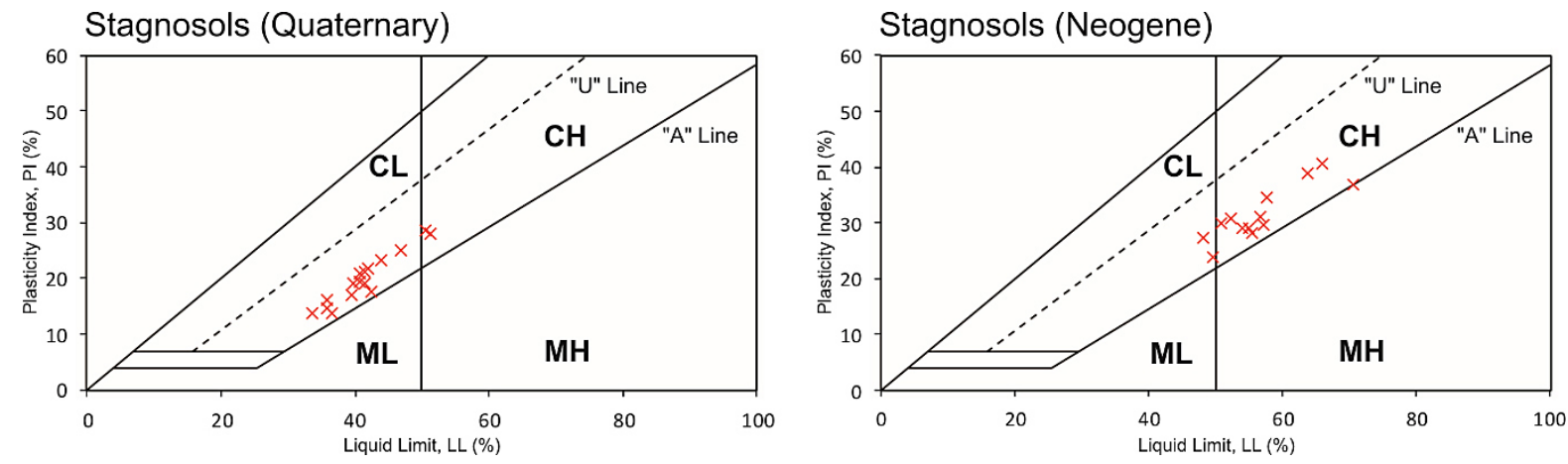

Figure 7: USCS samples distribution on plasticity chart on alluvium

presence of illite in the west, due to the appearance of marl, which is composed of different calcite to clay ratio. The disintegration of such deposits produces illitic clay which is washed away and transported to the southeast (Korolija and Jamičić, 1989).

Other alluvial soils of the northern and eastern parts of the research area, as the parent material, have a loess substrate with the presence of kaolinite clays corresponding to the genetic type of Pleistocene and Holocene sediments (Šparica et al., 1986). All alluvial soils with the parent material from this period are classified in the CL soil group.

Among other analysis results (humus content, porosity, water capacity, air capacity, specific volume weight and specific soil weight) obtained during the development of the BSM, only the humus content data is com- plete for the entire research area. No correlation was found between the proportion of humus and soil types according to the USCS, and the proportion of humus cannot be taken as a factor when it comes to modelling and predicting the soil types according to the USCS (Gambill et al., 2016).

After the analysis, the final product of the research was made - a map of soil trafficability for vehicles (see Figure 8). According to the analysis of the pedological units, the corresponding RCI values were added for the respective USCS soil groups, where the results from the Defence Mapping Agency Hydrographic/Topographic Centre (1982) were implemented for the present USCS group of soils. Figure 8 shows the soil trafficability indices in three different scenarios for three different soil moisture conditions: dry (a), moist (b) and wet (c). 
a)

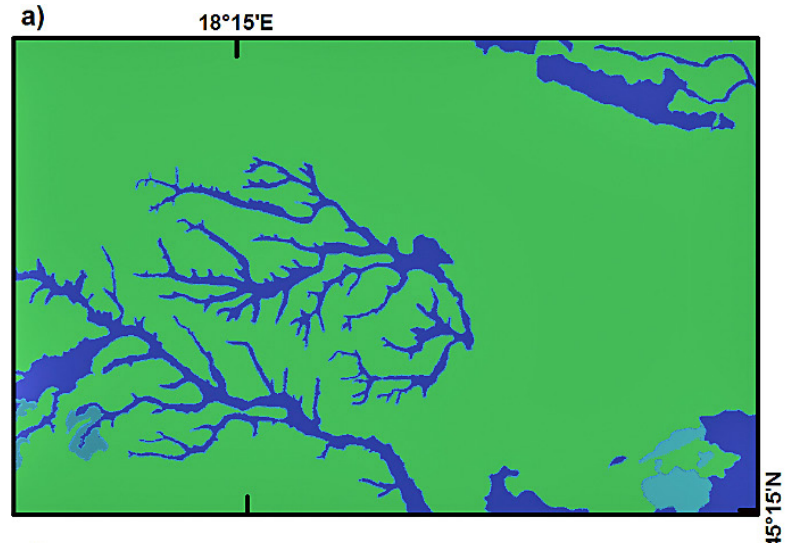

c) b)

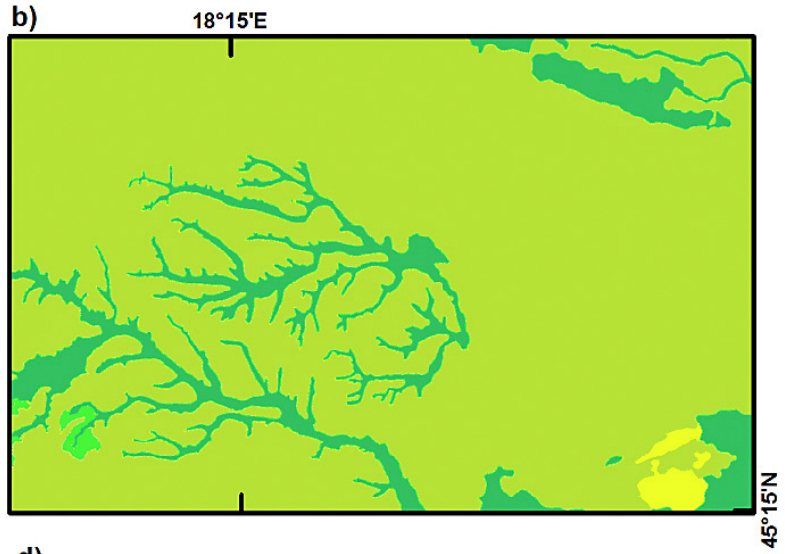

$18^{\circ} 30^{\circ} \mathrm{E} \mathrm{d)}$
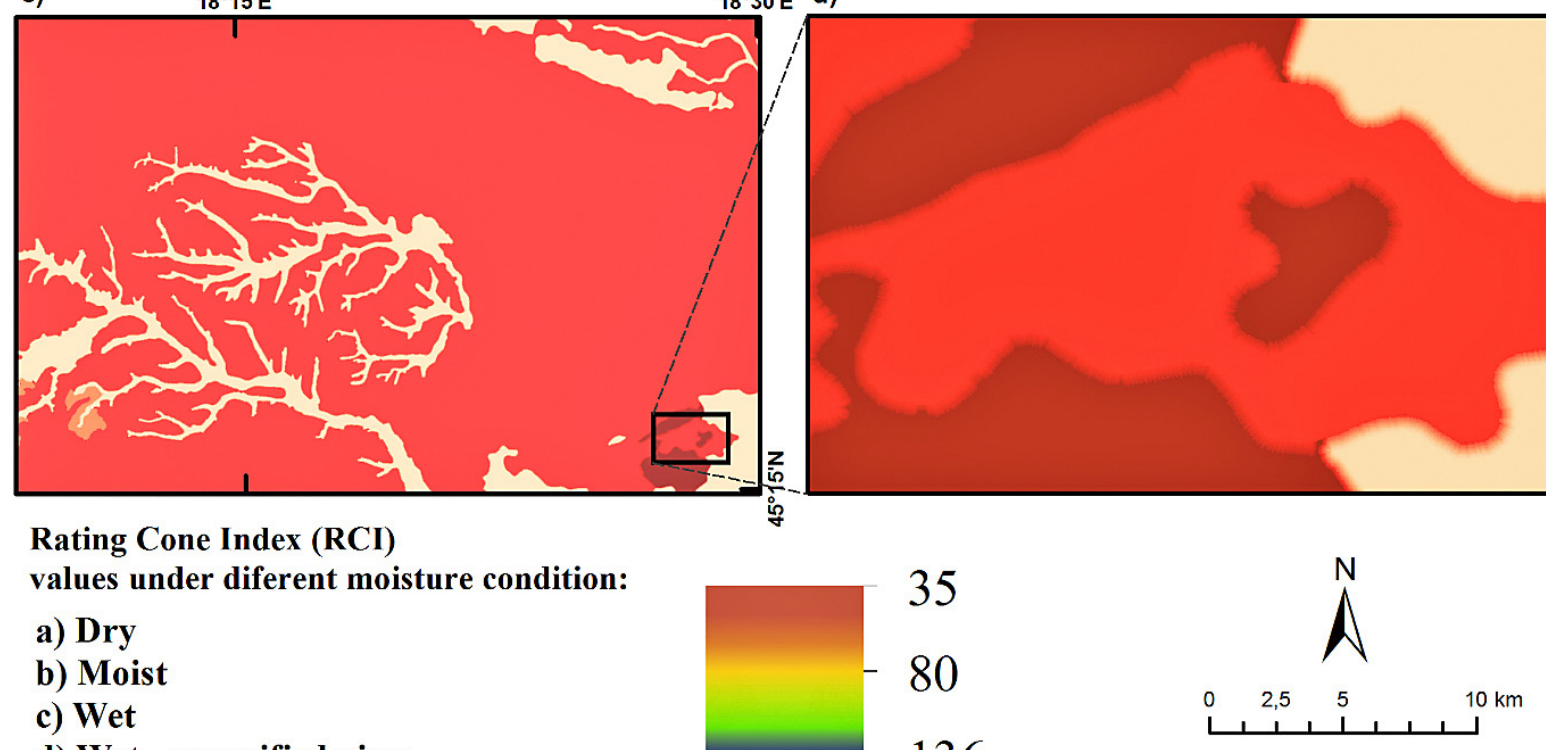
values under diferent moisture condition:
a) Dry
b) Moist
c) Wet
d) Wet - magnified view
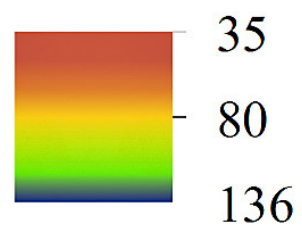

Figure 8: Fuzzified soil trafficability map for different soil moisture conditions

The highest RCI values are in dry soil conditions where soil conditions don't represent any limitations for the movement of any type of vehicle. With an increase of moisture content, the trafficability of soil decreases, so in wet conditions, the movement of vehicles in areas with high VCI would not be possible. Figure 8 (d) more clearly depicts the applied fuzzy logic mapping method that perfectly interprets the nature of the soil, i.e. its overlapping and unsharp boundaries between the soil groups (Sunila et al., 2004; McBratney et. al., 2003; Rybansky et al., 2015).

\section{Conclusions}

This study aimed to determine whether there is a possibility of using existing pedological data, the original basis of which is the BSM, to predict physical properties of the soils and map the vehicle trafficability on the present soils. By comparing the results of the samples (50) extracted at identical locations, it was found that there is no clear and direct relationship between the USDA and the USCS. Upon the implementation of further analyses, the results showed that in the case of $66 \%$ (6 of 9) soil types, there was a clear correlation between the BSM soil type and the soil type according to the USCS. All non-correlated soils are related to alluvium soils, where stagnosol is the dominant member. Further spatial analysis revealed that the main determinant of alluvial soil types according to the USCS is the parent material from which the soil was formed. The CLs originates from the Quaternary Period, whereas the $\mathrm{CH}$ group, which was transported and deposited along watercourses, had been formed on the soils that originate from an older geologic period, namely the Pliocene and Miocene. According to the results, geological units must be reliable factors and not left out from the modelling process of soil types according to the USCS. Therefore, the BSM soil type alone is not enough for a successful mapping of soil trafficability for the vehicles. We could not establish a connection between the ratios of the organic content (humus) with USCS soil types. For that reason, it could not be used as a relevant indicator to predict the soil classification according to the USCS for the soil types present in this area. 
The assumed sampling density in the field was satisfactory and further work on a national level may assume that lower density sampling is required for the present types of soils in the research area, except in alluvial soils where denser sampling is necessary. The physical properties of the alluvial soils are predisposed by the parent material from the place of origin, so they undergo the most dynamic changes of wet and dry periods and are therefore the riskiest in terms of vehicle cross-country mobility.

\section{Acknowledgment}

Soil analyses were carried out with funds earmarked for the project named "GIS Model of Terrain Trafficability" of the VoGIS Department, Centre for Defence and Strategic Studies "Janko Bobetko", Croatian Defence Academy "Dr Franjo Tuđman". I would like to thank Prof. PhD. Biljana Kovacevic Zelić, Geomechanical Laboratory, Department of Mining Engineering and Geotechnics, Faculty of Mining, Geology and Petroleum Engineering and their employee Mrs. Evelina Oršulić for her dedicated soil processing and analyses.

\section{References}

ASTM D2216-10 (2010): Standard Test Methods for Laboratory Determination of Water (Moisture) Content of Soil and Rock by Mass. ASTM International, West Conshohocken, PA, www.astm.org, 7 p.

ASTM D2487-17 (2017): Standard Practice for Classification of Soils for Engineering Purposes (Unified Soil Classification System). ASTM International, West Conshohocken, PA, www.astm.org, $10 \mathrm{p}$.

ASTM D422-63(2007)e2 (2007): Standard Test Method for Particle-Size Analysis of Soils (Withdrawn 2016). ASTM International, West Conshohocken, PA, www.astm.org, 8 p.

ASTM D4318-17e1 (2017): Standard Test Methods for Liquid Limit, Plastic Limit, and Plasticity Index of Soils. ASTM International, West Conshohocken, PA, www.astm.org, $20 \mathrm{p}$.

Bekker, M. G. (1956): Theory of Land Locomotion. University of Michigan Press, Ann Arbor, 522 p.

Bogunović, M. (1973a): Tla sekcije Vinkovci - 1, u mjerilu 1:50 000 (stručni izvještaj) (Soils of section Vinkovci -1, in scale 1:50 000 (technical report)). Institut za pedologiju i tehnologiju tla poljoprivrednog fakulteta sveučilišta u Zagrebu, Zagreb, 58 p. (in Croatian - no English abstract)

Bogunović, M. (1973b): Pedološka karta SFRJ. Vinkovci 1. 1:50000 (Pedological map of SFRY. Vinkovci 1. 1:50000). Projektni savjet za izradu pedološke karte SRH, Zagreb.

Bogunović, M. and Rapaić, M. (1993): Digitalizacija osnovne pedološke karte Republike Hrvatske (Digitalization of the Basic Pedological Map of the Republic of Croatia). Bilten Savjeta za daljinska istraživanja i fotointerpretaciju, 12, 65-75. (in Croatian - no English abstract)

Defense Mapping Agency Hydrographic/Topographic Center (1982): Defense Mapping Agency Procedural Guide for the Proiduction of the Sythesized Cross-Country Move- ment Compilation Overlay(s), Scale 1:50,000, Washington D.C., 29 p.

Frankenstein, S. (2008): FASST Soil Moisture, Soil Temperature: Original Versus New. Engineer Research and Development Center, Vicksburg, 36 p.

Gambill, D. R., Wall, A., Fulton, A. and Howard, H. (2016): Predicting USCS soil classification from soil property variables using Random Forest. Journal of Terramechanics, ISTVS, 65, 85-92. doi: 10.1016/j.jterra.2016.03.006.

García-Gaines, R. A. and Frankenstein, S. (2015): USCS and the USDA Soil Classification System, Development of a Mapping Scheme. US Army Corps of Engineers, Vicksburg, $36 \mathrm{p}$.

Hengl, T. and Reuter, H. I. (2009): GEOMORPHOMETRY Concepts, Software, Applications. Developments in soil science - Volume 33. Elsavier, 765 p. doi: 10.1017/ CBO9781107415324.004.

Heštera, H. and Pahernik, M. (2018): Physical-geographic factors of terrain trafficability of military vehicles according to Western World methodologies. Hrvatski geografski glasnik/Croatian Geographical Bulletin, 80, 2, 5-31. doi: 10.21861/hgg.2018.80.02.01.

Hofmann, A., Hoskova-Mayerova, S. and Talhofer, V. (2013): Usage of Fuzzy Spatial Theory for Modelling of Terrain Passability. Advances in Fuzzy Systems, 1-7. doi: 10.1155/2013/506406.

Husnjak, S. (2014): Sistematika tala Hrvatske (Systematics of Croatian Soils). Hrvatska sveučilišna naklada, Zagreb, 373 p. (in Croatian - no English abstract)

Korolija, B. and Jamičić, D. (1989): Osnovna geološka karta SFRJ 1:100 000. List Našice L 34-85 (Basic geological map SFRY 1:100 000. Sheet Našice L 34-85). Geološki zavod Zagreb (1988. - 1989.), Savezni geološki zavod, Beograd.

Korolija, B. and Jamičić, D. (1989): Osnovna geološka karta SFRJ 1:100 000, Tumač za list Našice L 34-85 (Basic geological map SFRY 1:100 000. Map explanation for sheet Našice L 34-85). Geološki zavod Zagreb (1988.), Savezni geološki zavod, Beograd, 36 p. (in Croatian - no English abstract)

Lagacherie, P., McBratney, A.B. and Voltz, M. (eds) (2007): Digital soil mapping. An introductory perspective. Developments in soil science. vol 31. Elsevier, Amsterdam, 658 p.

Malvić, T. (2008): Kriging, cokriging or stochastical simulations, and the choice between deterministic or sequential approaches. Geologia Croatica, 61, 1, 37-47.

McBratney, A.B., Santos, M.L.M. and Minasny, B. (2003): On digital soil mapping. Geoderma, 117, 3-52.

McKenzie, N. J. and Ryan, P. J. (1999): Spatial prediction of soil properties using environmental correlation. Geoderma, 89(1-2), 67-94. doi: 10.1016/S0016-7061(98)00137-2.

Mesić-Kiš, I. (2017): Contribution to the application and terminology of geostatistical mapping methods in Croatia Universal Kriging. The Mining-Geology-Petroleum Engineering Bulletin, 32(4), 31-36. doi: 10.17794/rgn.2017.4.3

Meyer, M. P. (1976): A Bibliography with Abstracts of US Army Engineer Waterways Experiment Station Publica- 
tions Related to Vehicle Mobility. Army Engineer Waterways Experiment Station, Vicksburg, 434 p.

Priddy, J. D. and Willoughby, W. E. (2006): Clarification of vehicle cone index with reference to mean maximum pressure. Journal of Terramechanics, 43(2), 85-96. doi: 10.1016/j.jterra.2004.10.001.

Rowland, D. (1972): Tracked vehicle ground pressure and its effect on soft ground performance. In: Proceedings of 4th ISTVS International Conference. Stockholm: ISTVS, 353-384.

Rybansky, M., Hofmann, M., Hubacek, M., Kovarik, V. and Talhofer, V. (2015): Modelling of cross-country transport in raster format. Environmental Earth Sciences, 74(10), 7049-7058. doi: 10.1007/s12665-015-4759-y.

Soil Science Division Staff (2017): Soil Survey Manual. Ditzler, C., Scheffe, K. and Monger, H.C. (eds.) USDA Handbook 18, Government Printing Office, Washington D.C., 603 p. doi: 10.1097/00010694-195112000-00022.

Soil Survey Staff (1951): Soil Survey Manual. U.S. Deptepartment of Agriculture Handbook 18, Government Printing Office, Washington D.C., 503 p.

Stevens, M., Towne, B., Mason, G., Priddy, J., Osorio, J. and Barela C. (2013): Procedures for One-Pass Vehicle Cone Index (VCI 1) Determination for Acquisition Support. The US Army Engineer Research and Development Center (ERDC), Vicksburg, 59 p.

Sunila, R., Laine, E. and Kremenova, O. (2004): Fuzzy Model and Kriging for Imprecise Soil Polygon Boundaries. In: Brandt, S.A. (eds.): Proc. 12th Int. Conf. on Geoinformatics - Geospatial Information Research: Bridging the Pacific and Atlantic, University of Gävle, 489-495.

Šparica, M., Buzaljko, R. and Mojićević, M. (1986): Osnovna geološka karta SFRJ 1:100 000, List Slavonski Brod L
34-97 (Basic geological map SFRY 1:100 000. Sheet Slavonski Brod L 34-97). „Geoinženjering“ OOUR institut za geologiju Sarajevo (1986.), Savezni geološki zavod, Beograd.

Šparica, M., Buzaljko, R. and Pavelić, D. (1986): Osnovna geološka karta SFRJ 1:100 000, Tumač za list Slavonski Brod L 34-97 (Basic geological map SFRY 1:100 000. Map explanation for sheet Slavonski Brod L 34-97). „Geoinženjering“ OOUR institut za geologiju Sarajevo (1986.), Savezni geološki zavod, Beograd, 52 p. (in Croatian - no English abstract)

Vidaček, Ž. (1973a): Tla sekcije Slavonski Brod 2, u mjerilu 1:50 000 (stručni izvještaj) (Soils of section Slavonski Brod 2, in scale 1:50 000 (technical report)). Institut za pedologiju i tehnologiju tla poljoprivrednog fakulteta sveučilišta u Zagrebu, Zagreb, 36 p. (in Croatian - no English abstract)

Vidaček, Ž. (1973b): Pedološka karta SFRJ, Slavonski Brod 2 , 1:50000 (Pedological map of SFRY, Slavonski Brod 2, 1:50000). Projektni savjet za izradu pedološke karte SRH, Zagreb.

Wong, J. Y. (2001): Theory of ground vehicles, Third Edition. John Wiley \& Sons, INC. New York, 528 p. doi: 10.1017/ CBO9781107415324.004.

Zhu, A.X., Hudson, B., Burt, J., Lubich, K. and Simonson, D. (2001): Soil mapping using GIS, expert knowledge, and fuzzy logic. Soil Science Society of America Journal, 65, 1463-1472.

Zinck, J. A., Metternicht, G., Bocco, G. and Del Valle, H.F. (eds) (2016): Geopedology. An Integration of Geomorphology and Pedology for Soil and Landscape Studies. Springer, New York, 550 p. doi: 10.1007/978-3-31919159-1 


\section{SAŽETAK}

\section{Analiza pedoloških čimbenika i USCS-a na kontaktnome prostoru đakovačke lesne zaravni i pobrđa Dilj-gore, Hrvatska}

U radu se istražuju pedološki čimbenici u podjeli tla Unified Soil Classification System (USCS) na kontaktnome području đakovačke lesne zaravni i pobrđa Dilj-gore. Istraživanje je provedeno s ciljem izrade karte terenske prohodnosti tla za vozila. U prostornu GIS analizu uključene su pedološke jedinice Osnovne pedološke karte (BPM) u mjerilu $1: 50$ ooo, koje unutar sebe sadržavaju raspodjelu pedoloških jedinica prema bazi World Reference Base (WRB), granulometrijsku razdiobu prema United States Department of Agriculture (USDA), klasifikaciji tla i udjelu humusa, te podatke Opće geološke karte 1 : 100 ooo (BGM) kao izvorišnoga matičnog supstrata od kojega je tlo nastalo. Provedeno je terensko uzorkovanje (72 uzorka) i laboratorijska analiza uzoraka prema USCS-u. Uzorci su uzimani na istovjetnim mjestima (50 uzoraka) kao i profili vađeni tijekom izrade BPM-a kako bi se omogućila usporedba dvaju klasifikacijskih sistema. Provedbom analiza nije utvrđena jasna statistička veza između USDA i USCS klasifikacija tla. Podudarnost pedoloških jedinica BPM-a i glina niske plastičnosti (CL) jasno je vidljiva kod svih jedinica, osim kod jedinica koje se nalaze na aluviju. Amfiglejna tla na aluviju imaju prisustvo CL-a i glina visoke plastičnosti (CH). Uključivanjem geološke osnove u prostornu analizu utvrđeno da CL pripadaju izvorišnim dijelovima kvartarne starosti, dok su CH nastale na matičnome supstratu neogenske starosti. Obrada rezultata i kartografski prikaz rezultata prema metodi konusnoga indeksa Waterways Experiment Station (WES) dobiveni su primjenom neizrazite logike. Principi neizrazite logike korišteni su na dodirima pedoloških jedinica zbog nemogućnosti definiranja jasnih granica pojavnosti, odnosno prestanaka prisutnosti određenoga tipa tla.

\section{Ključne riječi:}

USDA klasifikacija tla, USCS, mehanika tla, neizrazita logika, terenska mobilnost vozila

\section{Author contribution}

Hrvoje Heštera (professor of geography, captain - army officer) completed the entire research and publishing process, as a part of his $\mathrm{PhD}$ thesis research about physical geographical factors of terrain trafficability for vehicles. Soil sample classification according to USCS were completed by employees of the Geomechanical Laboratory, Department of Mining Engineering and Geotechnics, at the Faculty of Mining, Geology and Petroleum Engineering in Zagreb. 